Marnia Yasin. Analisis Kebenaran Informasi dan Kegunaan Situs Web BP PACD dan 2021 Dikmas Nusa Tenggara Timur

\title{
ANALISIS KEBENARAN INFORMASI DAN KEGUNAAN SITUS WEB BP PAUD DAN DIKMAS NUSA TENGGARA TIMUR
}

\author{
Marnia Yasin' \\ 1)Program Studi Sistem Informasi \\ Sekolah Tinggi Manajemen Informatika Komputer (STIKOM) Uyelindo \\ Jl. Perintis Kemerdekaan I, Kota Kupang, Nusa Tenggara Timur \\ Email: nial7birohukum@gmail.com
}

\begin{abstract}
ABSTRAK
BP PAUD Dan Dikmas NTT merupakan sebuah instansi yang memiliki begitu banyak mitra satuan pendidikan yang tersebar di setiap kabupaten/kota dan dalam rangka mendukung kebijakan sistem pemerintahan berbasis elektronik (SPBE) maka BP PAUD Dan Dikmas NTT telah membangun dan menerapkan situs web responsive yang lahir sebagai pendukung layanan informasi publik terhadap mitra, masyarakat umum maupun instansi. Sebagai media informasi, situs web ini perlu dievaluasi dari segi kebenaran informasi yang dipublikasikan dan kegunaannya untuk mengetahui apakah situs web telah mampu mencapai tujuannya sebagai media pendukung layanan informasi yang faktual dan berguna pada BP PAUD Dan Dikmas NTT. Adapun tujuan yang hendak dicapai dari penelitian ini adalah untuk menganalisis kebenaran informasi yang dipublikasikan pada situs web BP PAUD Dan Dikmas NTT berdasarkan faktor/variabel pada Teori Literasi Informasi serta mengevaluasi kegunaan dari situs web tersebut berdasarkan metode WEBUSE guna memberikan rekomendasi perbaikan guna memenuhi persyaratan sebagai sebuah media informasi berbasis web yang faktual dan berguna. Adapun hasil dari penelitian ini adalah dari aspek kebenaran informasi berdasarkan Teori Literasi Informasi memperoleh rerata skor 4 atau dikategorikan dalam keadaan baik/tinggi, sedangkan dari aspek kegunaan, perhitungan poin usability yang dilakukan berdasarkan metode WEBUSE memperoleh poin usability sebesar 0,66 atau termasuk dalam level "Good". Hasil ini menunjukkan bahwa situs web BP PAUD Dan Dikmas NTT dapat dikatakan telah memenuhi syarat sebagai sebuah media informasi berbasis web yang faktual dan berguna tetapi dengan beberapa permasalahan minor yang harus diperbaiki atau ditingkatkan.
\end{abstract}

Kata kunci: Kebenaran informasi, kegunaan, situs web, SPBE, Teori Literasi Informasi, WEBUSE.

\section{ABSTRACT}

BP PAUD Dan Dikmas East Nusa Tenggara is agent that has many educational unit partners spread across every district/city and in order to support the policy of an electronic-based government system (SPBE), BP PAUD Dan Dikmas East Nusa Tenggara have built and implemented responsive websites that were born as supporting public information services to partners, the general public and agencies. As an information media, this website needs to be evaluated in terms of the reliability of published information and its usability to find out whether the website has been able to achieve its objectives as a support media for factual and useful information services at BP PAUD Dan Dikmas East Nusa Tenggara. The purpose of this research is to analyze the reliability of information published on the BP PAUD Dan Dikmas East Nusa Tenggara websites based on factors/variables in Information Literacy Theory and evaluate the usability of the website based on the WEBUSE method to provide recommendations for improvements to meet the requirements as a factual and useful web-based information media. The results of this research are from the aspect of reliability of information based on Information Literacy Theory obtains a mean score of 4 or is categorized in good/high condition, while from the usability aspect, the calculation of usability points carried out based on the WEBUSE method earns usability points of 0.66 or is included in the level "Good". These results indicate that the website of BP PAUD Dan Dikmas East Nusa Tenggara can be said to have met the requirements as a webbased information media that is factual and useful but with some minor problems that must be fixed or improved.

Keywords: Information Literacy Theory, information reliability, SPBE, usability, website, WEBUSE. 


\begin{tabular}{c|l} 
Jurnal Sains Komputer dan Teknologi Informasi & Page \\
e-issn: 2655-7460. Volume 3 No.2, Mei 2021 & 29-39 \\
\hline
\end{tabular}

\section{PENDAHULUAN}

Balai Pengembangan Pendidikan Anak Usia Dini dan Pendidikan Masyarakat Nusa Tenggara Timur (BP PAUD Dan Dikmas NTT) merupakan sebuah instansi vertikal di bawah Ditjen PAUD, Dikdas dan Dikmen Kementerian Pendidikan dan Kebudayaan Republik Indonesia dengan tugas utama yaitu melaksanakan pengembangan program mutu pendidikan bagi anak usia dini dan pendidikan masyarakat (BP PAUD Dan Dikmas NTT, 2020). Tugas tersebut dirincikan ke dalam berbagai fungsi yang salah satunya adalah pelaksanaan kemitraan di bidang pendidikan anak usia dini dan pendidikan masyarakat. Mitra yang dimaksud dalam fungsi tersebut yakni lembaga atau satuan pendidikan seperti TK/PAUD, PKBM dan SKB di 22 kabupaten/kota di NTT.

Mengingat bahwa BP PAUD Dan Dikmas NTT memiliki begitu banyak mitra yakni 5.562 satuan pendidikan yang tersebar di setiap kabupaten/kota (Kemdikbud, 2020) dan dalam rangka mendukung kebijakan sistem pemerintahan berbasis elektronik (SPBE) maka BP PAUD Dan Dikmas NTT telah membangun dan menerapkan beberapa sistem berbasis teknologi komputer, salah satunya dalam bentuk situs web. Situs web BP PAUD Dan Dikmas NTT merupakan sistem responsive yang lahir sebagai pendukung layanan informasi publik terhadap mitra, masyarakat umum maupun instansi terkait guna mencapai penyelenggaraan pemerintahan yang transparan, efektif, efisien, akuntabel dan dapat dipertanggungjawabkan sesuai dengan amanat Undang-Undang nomor 14 tahun 2008 tentang Keterbukaan Informasi Publik.

Sebagai media informasi, situs web dengan alamat https://bppauddikmasntt.kemdikbud.go.id yang telah online sejak bulan Januari 2018 ini perlu dievaluasi dari segi kebenaran informasi yang dipublikasikan dan kegunaannya untuk mengetahui apakah situs web telah mampu mencapai tujuannya sebagai media pendukung layanan informasi yang faktual dan berguna pada BP PAUD Dan Dikmas NTT. Evaluasi terhadap situs web BP PAUD Dan Dikmas NTT penting dilakukan karena investasi yang sangat besar dari pemerintah dalam memberikan layanan berbasis elektronik dan juga karena laju pertumbuhan yang besar dalam penerapan sistem pemerintahan berbasis elektronik (Rochmansjah, 2019).

Berdasarkan fakta yang telah dibahas maka pada penelitian ini akan dilakukan analisis terhadap situs web
BP PAUD Dan Dikmas NTT sebagai sebuah media informasi berdasarkan Teori Literasi Informasi dan metode Website Usability Evaluation (WEBUSE).

\section{TINJAUAN PUSTAKA}

\section{I. Pemanfaatan TIK dalam Pemerintahan}

Peranan teknologi informasi dan komunikasi dalam menunjang sistem operasional dan manajerial pada instansi pemerintahan dewasa ini dirasakan semakin penting. Mengingat akan pentingnya fungsi pengelolaan data dan informasi ini, terutama untuk mendukung kegiatan-kegiatan di instansi pemerintah maka wajar kalau pemerintah berupaya untuk menempatkan pengelolaan data dan informasi ini pada tempat yang setara dan sama pentingnya dengan pengelolaan sumberdaya lainnya, seperti halnya sumberdaya manusia, keuangan, waktu dan yang lainnya. Sistem informasi kini telah menjadi kerangka dasar bagi semua aktifitas pemerintahan dan memungkinkan bagi fungsi manajerial dalam melakukan upaya pengelolaan sumber daya yang dimiliki secara lebih efisien dan efektif (Amri, 20I6).

Berdasarkan laporan OECD (The Organisation for Economic Co-operation and Development) dalam Praditya (20/4), diketahui bahwa penggunaan TIK oleh pemerintahan memunculkan beberapa keuntungan, yakni:

a. Meningkatkan efisiensi, penggunaan TIK dapat meningkatkan efisiensi dalam berbagi data atau informasi di dalam maupun antarpemerintahan. Penggunaan TIK juga dapat meningkatkan efisiensi dalam pengumpulan (collecting) dan penyampaian (transmission) data, penyediaan informasi dan komunikasi. Begitu pula dalam memroses tugas dan operasi administrasi publik.

b. Meningkatkan pelayanan, penggunaan TIK dapat meningkatkan pelayanan terhadap masyarakat. Dalam menggunakan layanan publik, masyarakat tidak perlu mengetahui struktur dan hubungan kompleks dibalik layanan yang diberikan oleh pemerintah.

c. Membantu mencapai suatu kebijakan tertentu, penggunaan TIK dapat membantu menyosialisasikan kebijakan pemerintah kepada masyarakat sehingga pihak-pihak terkait dapat berbagi ide dan informasi terkait dengan suatu kebijakan tertentu.

d. Membantu kontribusi terhadap kebijakan ekonomi, penggunaan TIK dalam e-government dapat 
mengurangi korupsi, meningkatkan keterbukaan dan kepercayaan terhadap pemerintah. Pemerintah juga dapat melakukan penghematan melalui proses administrasi dan penyediaan informasi berbasis TIK. Begitu pula dengan kegiatan ekonomi di desa/kelurahan berbasis TIK (e-commerce maupun e-business) dapat didukung dengan penggunaan TIK.

e. Meningkatkan kontribusi terhadap reformasi, penggunaan TIK telah mengubah atau mereformasi berbagai bidang, seperti: memperbaiki transparansi dan fasilitasi berbagi informasi.

f. Meningkatkan kepercayaan antara pemerintah dengan masyarakatnya, penggunaan TIK dapat meningkatkan good governance melalui peningkatan transparansi, mengurangi korupsi sehingga dapat meningkatkan kepercayaan masyarakat terhadap penyelenggara pemerintah. Begitu pula jika aspirasi dan pendapat masyarakat dapat difasilitasi ataupun ditampung dalam media berbasis TIK yang digunakan oleh pemerintah.

\subsection{Teori Literasi Informasi}

Beberapa faktor/variabel yang harus diperhatikan dalam melakukan evaluasi terhadap informasi yang disajikan dalam situs web (online), yaitu: relevansi, akurasi, otoritas dan reputasi, objektivitas, kekinian, cakupan, bukti yang kuat, bahasa dan penulisan. Adapun penjelasan tentang setiap faktor/variabel tersebut sebagai berikut (Azwar, 2013):

\section{a. Relevansi}

Relevansi adalah penilaian tentang sejauh mana informasi yang dikandung suatu sumber informasi sesuai dengan masalah yang akan dibahas. Hal ini dapat dilakukan dengan cara melihat judul dan isi dari suatu sumber, baik tercetak maupun non cetak termasuk situs web (Ai Lien et al, 20I4).

Sebuah situs web yang baik akan menyatakan tujuan dari pembuatan situs tersebut. Misalnya, situs tersebut ditujukan untuk siapa, digunakan untuk membahas apa, dan dibuat untuk apa. Umumnya informasi semacam ini akan dilihat pada link About Us (tentang kami). Dengan membaca link About Us akan terlihat tingkat relevansi antara isi informasi yang terkandung dalam web tersebut dengan kebutuhan informasi pembaca.

b. Akurasi

Akurasi umumnya menunjukkan pada ketepatan yang faktual atau kebenaran dari suatu sumber informasi.
Menentukan keakuratan suatu informasi merupakan hal mendasar dari keseluruhan proses evaluasi dan hal tersebut sering kali menjadi alasan untuk mengkritisi suatu sumber informasi. Akurasi suatu informasi selalu dikaitkan dengan orang yang menulis atau yang bertanggung jawab atas informasi tersebut. Penjelasan mengenai akurasi suatu informasi dalam halaman web biasanya tercantum dalam menu About Us, Profile, atau Contact Us.

\section{c. Otoritas dan reputasi}

Menilai otoritas dari suatu sumber informasi didasarkan pada beberapa faktor, namun yang utama adalah faktor pengetahuan dan keahlian dari penanggungjawab yang menghasilkan informasi tersebut. Suatu sumber informasi umumnya memiliki otoritas jika ditulis oleh seseorang yang ahli atau diproduksi oleh sebuah lembaga yang dikenal memiliki keahlian dalam bidang tertentu. Otoritas terkait erat dengan reputasi, baik reputasi sumber informasi itu sendiri, maupun reputasi dari penanggungjawab yang memproduksi informasi tersebut. Reputasi yang baik tercipta karena informasi yang dihasilkan terbukti berhasil, bermanfaat atau berharga bagi orang banyak, atau penulis atau lembaga tersebut dikenal baik karena pengetahuan dan keahlian mereka. Otoritas dan reputasi sangat berpengaruh ketika ingin mengambil isi suatu informasi.

d. Kekinian

Kekinian (currency) dari suatu informasi berhubungan erat dengan seberapa baru (update) informasi tersebut. Kekinian juga menunjukkan bahwa informasi tersebut senantiasa diperbarui. Faktor kekinian sering kali menjadi faktor penting yang mempengaruhi orang menggunakan internet untuk mencari informasi, karena ada pandangan bahwa internet selalu menyediakan akses informasi terbaru. Disamping itu kekinian menjadi pertimbangan yang penting karena informasi yang ketinggalan zaman akan menjadi tidak berguna lagi, tidak akurat, tidak lagi relevan dan kadang menyesatkan.

\section{e. Objektivitas}

Objektivitas terkait erat dengan tujuan dari pembuatan situs. Situs yang baik akan menjelaskan tujuan dari situs tersebut. Misalnya, situs tersebut untuk siapa, digunakan untuk membahas apa, dan dibuat untuk apa. 


\begin{tabular}{c|l} 
Jurnal Sains Komputer dan Teknologi Informasi & Page \\
e-issn: 2655-7460. Volume 3 No.2, Mei 2021 & 29-39 \\
\hline
\end{tabular}

Umumnya informasi tersebut dapat dilihat pada menu About Us (tentang kami).

\section{f. Cakupan}

Cakupan (coverage) terkait dengan isi informasi atau dokumen dalam situs, seperti hal apa saja yang dibahas, seberapa dalam atau detail informasi yang disajikan dan adakah link yang terhubung.

\section{g. Bukti yang kuat}

Di samping cara-cara yang telah disebutkan di atas, ada cara lain untuk menilai atau mengevaluasi sumber informasi online, yaitu dengan membandingkan informasi yang diperoleh dengan informasi lainnya yang berasal dari situs lain yang terpercaya, apakah ada kesamaan ataukah perbedaan.

h. Bahasa dan gaya penulisan

Umumnya, penulis situs web yang tidak memiliki kredibilitas kurang memperhatikan aspek bahasa. Meskipun situs yang memiliki bahasa dan gaya penulisan yang bagus bukan merupakan indikator situs yang akurat, namun kecerobohan ini mungkin akan menjadikan situs tersebut kurang dapat diandalkan.

Penulis yang kredibel selalu memperhatikan aspek bahasa, seperti: pengejaan, tanda baca, kaidah bahasa, isi tulisan, gaya penulisan, dan sebagainya. Penulis yang berkualitas akan memperhatikan aspek bahasa seperti halnya dalam menerbitkan buku.

\subsection{WEBUSE}

Usability testing merupakan salah satu proses desain dalam User Centered Design yang dilakukan untuk mengetahui apakah sebuah produk sesuai dengan kriteria usability dengan melibatkan pengguna dalam pengujian (Akhsan dan Faizah, 2017). Pengujian usability dijalankan untuk mengetahui seberapa efektif, efisien dan memuaskan sebuah situs web menurut penggunanya. Singkatnya, pengujian usability dilakukan untuk mengukur sejauh mana manfaat dari sistem terhadap pengguna. Manfaat yang diharapkan tersebut belum tentu bisa tercapai jika sistem yang akan diterapkan tidak berguna atau tidak diterima karena tidak sesuai dengan kebutuhan (Tjiptabudi, 2018).

Web Usability Evaluation (WEBUSE) merupakan sebuah metode evaluasi usability yaitu berupa kuesioner evaluasi usability berbasis web yang memungkinkan pengguna menilai kegunaan situs web yang dievaluasi (Chiew dan Salim, 2003). WEBUSE merupakan suatu kuesioner yang dikembangkan dari empat buah usability evaluation tool, yaitu WAMMI, WebSAT, Bobby, dan Protocol Analysis untuk mengevaluasi usability dari sebuah situs web. Kuesioner ini terdiri dari 24 pernyataan dengan lima opsi tanggapan yang terbagi dalam empat dimensi/kategori, yaitu: Content, Organization, and Readability, Navigation and Links, Desain User Interface, Performance and Effectiveness. Proses yang dilakukan seperti pada gambar berikut:

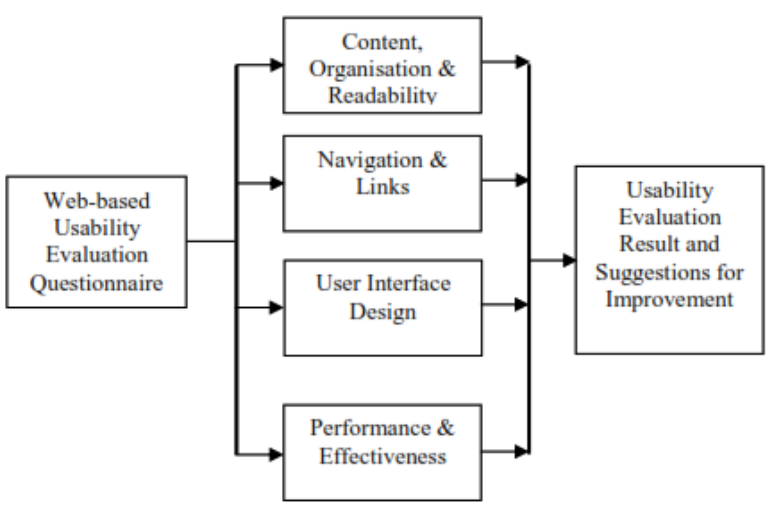

Gambar I. Proses evaluasi menggunakan metode WEBUSE

\section{a. Content, organization and readability}

Content yang baik adalah content yang mudah dipahami oleh pengguna, jelas, dan terorganisir dengan baik. Situs web yang terorganisir dengan baik dapat memberikan pemahaman yang cepat bagi pengguna (Marcus, 20II). Sedangkan, readability sebuah situs web diukur melalui apakah sistem berfungsi dengan benar dan memberikan informasi yang akurat (Baltzan dan Phillips, 2009).

\section{b. Navigation and link}

Metode yang digunakan untuk mencari dan mengakses informasi dalam situs web secara efektif dan efisien untuk membantu pengguna situs web disebut dengan Navigation. Sedangkan, links berfungsi menghubungkan pengguna dengan cara memilih dan mengklik links pada halaman hypertext (homepage), yang menyebabkan terbukanya halaman baru. Links yang baik harus menggunakan teks daripada grafis sehingga mudah dipahami oleh pengguna (Marcus, 20I I).

c. User interface design

User interface design merupakan sebuah metode dan prosedur yang membutuhkan pertimbangan dengan baik saat merancang dan mengembangkan situs web. Hal yang penting dalam merancang user interface diantaranya 
menetapkan tujuan, menentukan pengguna dan menyediakan content yang bermanfaat. Untuk memastikan hasil yang terbaik perlu mempertimbangkan berbagai isu-isu user interface design dan unjuk kerja yang baik bagi pengguna (Marcus, 20I I).

d. Performance and effectiveness

Performance situs web dapat diukur dengan cara seberapa cepat suatu situs web melakukan proses atau transaksi tertentu sehingga menghasilkan kinerja pengguna yang cepat dan efisien (Baltzan dan Phillips, 2009). Sedangkan, effectiveness merupakan keberhasilan sebuah situs web menghasilkan informasi yang tepat bagi pengguna (Marcus, 20I I).

Beberapa tahap dalam pengujian usability menggunakan kuesioner WEBUSE adalah:

a. Menentukan sistem web yang akan dievaluasi.

b. Responden memberi tanggapan untuk semua pernyataan yang ada pada kuesioner.

c. Merit digunakan berdasarkan tanggapan dari user untuk setiap pernyataan, kemudian diakumulasi untuk setiap kategori usability.

d. Poin kategori usability adalah mean value dari masing-masing kategori.

e. Poin usability dari situs web adalah mean value dari masing-masing kategori.

f. Level usability ditentukan berdasarkan poin usability.
Ke-5 (lima) pilihan tanggapan yang tersedia untuk setiap pernyataan dan hasil kuesioner akan akan diubah dalam bentuk merit. Hubungan pilihan dan merit dapat dilihat pada Tabel I.

Tabel I. Kesesuaian merit dan pilihan tanggapan (Chiew dan Salim, 2003)

\begin{tabular}{cccccc}
\hline Pilihan & $\begin{array}{c}\text { Sangat } \\
\text { Tidak } \\
\text { Setuju }\end{array}$ & $\begin{array}{c}\text { Tidak } \\
\text { Setuju }\end{array}$ & Netral & Setuju & $\begin{array}{c}\text { Sangat } \\
\text { Setuju }\end{array}$ \\
\hline Merit & 0,00 & 0,25 & 0,50 & 0,75 & 1,00 \\
\hline
\end{tabular}

Kemudian merit diakumulasikan berdasarkan 5 kategori usability. Mean value untuk setiap kategori dianggap sebagai poin usability untuk setiap kategori. Poin usability untuk kategori $x$ didefinisikan dalam rumus sebagai berikut:

$x=\frac{\left.\left[\sum \text { (Merit untuk setiap pertanyaan pada kategori }\right)\right\}}{[\text { Jumlah pertanyaan }]}$

Hasil keseluruhan poin usability situs web adalah mean value dari poin usability ke-4 (empat) kategori. Level usability ditentukan berdasarkan besaran poin usability. Tabel 2 berikut menunjukkan hubungan poin usability dan level usability beserta penjelasannya.

Tabel 2. Hubungan poin usability dan level usability

\begin{tabular}{cccccc}
\hline Poin, $\mathrm{x}$ & $\begin{array}{c}0<=\mathrm{x}<= \\
0,2\end{array}$ & $\begin{array}{c}0,2<=\mathrm{x}<= \\
0,4\end{array}$ & $\begin{array}{c}0,4<=\mathrm{x} \\
<=0,6\end{array}$ & $\begin{array}{c}0,6<=\mathrm{x} \\
<=0,8\end{array}$ & $\begin{array}{c}0,8<=\mathrm{x}<= \\
1,0\end{array}$ \\
\hline $\begin{array}{c}\text { Level } \\
\text { usability }\end{array}$ & Bad & Poor & Moderate & Good & Excellent \\
\hline
\end{tabular}

\subsection{Penelitian Terkait}

Adapun beberapa penelitian sebelumnya telah mengevaluasi performa sebuah situs web sebagai media informasi jika dilihat dari aspek kebenaran informasi dan kegunaannya, tetapi penelitian-penelitian tersebut bersifat terpisah atau belum mengkombinasikan kedua aspek yang dimaksud dalam sebuah penelitian yang sama. Dahlan (2016) dalam penelitiannya untuk mengevaluasi informasi online pada situs web perpustakaan UIN Syarif Hidayatullah berpendapat bahwa suatu situs web harus menyediakan informasi yang akurat, tepat dan berasal dari sumber yang terpercaya, oleh karena itu dibutuhkan suatu keterampilan literasi informasi untuk mengevaluasinya. Literasi informasi digunakan karena memiliki unsur yang lengkap dan baik digunakan untuk penentuan kebenaran sebuah informasi. Pada penelitian lainnya, Dewi et al (2018) menggunakan WEBUSE untuk menganalisis kegunaan dari sebuah aplikasi mobile pemesanan layanan Taksi Perdana. WEBUSE digunakan karena dapat mengumpulkan kepuasaan subjektif dan kesan pengguna terhadap sebuah situs web dengan tool yang terstruktur dan akurat. Karena hal itu dalam penelitian ini akan dilakukan dengan metode WEBUSE sebagai user based method untuk mengevaluasi.

\section{METODE PENELITIAN}

\section{I. Metode Pengumpulan Data}




$$
\begin{array}{c|l}
\text { Jurnal Sains Komputer dan Teknologi Informasi } & \text { Page } \\
\text { e-issn: 2655-7460. Volume } 3 \text { No.2, Mei 2021 } & \text { 29-39 }
\end{array}
$$

Pengumpulan data yang dilakukan dalam penelitian ini adalah dengan cara:

\section{a. Kuesioner}

Pada penelitian ini menggunakan kuesioner sebagai metode pengumpulan data yang utama. Dalam penyusunan kuesioner mengacu pada 8 (delapan) variabel pada Teori Literasi Informasi dan 4 (empat) variabel pada metode WEBUSE.

\section{b. Observasi}

Observasi pada penelitian ini digunakan untuk mengamati dan mencatat kejadian-kejadian faktual yang terjadi selama pelaksanaan. Dalam melaksanakan metode ini, dilakukan observasi secara langsung pada situs web BP PAUD Dan Dikmas NTT sebagai pembanding dengan data yang terkumpul menggunakan kuesioner.

c. Wawancara (Interview)

Metode ini dilakukan dengan mengajukan pertanyaanpertanyaan secara terstruktur sesuai pedoman wawancara kepada sumber informasi dan dijawab secara langsung. Dalam hal ini wawancara dilakukan terhadap pengelola situs web BP PAUD Dan Dikmas NTT.

d. Studi Pustaka

Dilakukan dengan kegiatan mencari literatur atau sumber pustaka pendukung penelitian yang mampu menyelesaikan dan memberikan informasi yang memadai serta membantu mempertegas teori-teori yang ada.

\subsection{Tahapan Penelitian}

Tahapan-tahapan yang dilalui oleh peneliti dimulai dari permulaan berupa studi literatur, pelaksanaan evaluasi (pengumpulan data), analisis hingga kesimpulan yang membentuk sebuah alur yang sistematis. Tahapan penelitian ini digunakan sebagai pedoman peneliti dalam pelaksanaan penelitian agar hasil yang dicapai sesuai dengan tujuan yang telah ditentukan sebelumnya. Selengkapnya dapat dilihat pada gambar berikut:



Gambar 2. Tahapan penelitian

Berdasarkan Gambar 2, maka dapat dijelaskan sebagai berikut:

a. Studi literatur

Pada tahap ini dilakukan pengumpulan data awal yang berkaitan dengan penelitian. Pengumpulan data ini berupa pencarian referensi-referensi dari jurnal serta buku cetak guna mendukung penelitian.

\section{b. Pelaksanaan evaluasi}

Pada tahap ini dilakukan penyebaran kuesioner, observasi dan wawancara guna memperoleh data yang akan dianalisis.

c. Analisis hasil evaluasi

Pada tahap ini akan dilakukan analisis validitas dan reliabiltas terhadap instrumen, dilakukan perhitungan terhadap hasil kuesioner dengan menggunakan analisis mean dan total variabel dari ke-8 variabel pada Teori Literasi Informasi serta perhitungan poin usability berdasarkan 4 variabel pada WEBUSE. 
d. Kesimpulan dan pemberian rekomendasi

Pada tahap ini hasil analisis data akan dipaparkan dalam bentuk grafik maupun kualitatif, dilakukan perbandingan antara hasil analisis data dari kuesioner dengan hasil observasi yang dilakukan. Setelah itu akan ditarik kesimpulan dari hasil analisis serta pengusulan rekomendasi-rekomendasi untuk perbaikan dan pengembangan situs web BP PAUD Dan Dikmas NTT ke depannya.

\section{HASIL DAN PEMBAHASAN}

\section{I. Populasi dan Sampel}

Pada penelitian ini, yang menjadi populasi penelitian adalah pegawai, mitra dan masyarakat umum sehingga populasi dianggap tidak diketahui pasti. Maka untuk penentuan jumlah sampel mengacu pada pernyataan Hair et al (2010) bahwa banyaknya sampel sebagai responden harus disesuaikan dengan banyaknya variabel yang akan digunakan pada kuesioner, dengan asumsi $\mathrm{n} \times 5$ observed variable sampai dengan $\mathrm{n} \times 10$ observed variable. Cara ini digunakan pada populasi yang tidak diketahui dengan pasti jumlahnya.

Maka pada penelitian ini, perhitungan untuk penentuan jumlah responden yang digunakan adalah 12 variabel (8 variabel pada Teori Literasi Informasi dan 4 variabel pada WEBUSE) pada kuesioner dikali 5 (konstanta minimal) sehingga diperoleh hasil 60 orang responden sebagai sampel.

Teknik sampling yang digunakan adalah accidental sampling, yaitu teknik penentuan sampel yang dilakukan atas dasar seadanya, tanpa direncanakan terlebih dahulu atau dilakukan secara kebetulan selama orang yang ditemukan itu dipandang cocok sebagai sumber data.

\subsection{Karakteristik Responden}

Karakteristik responden menjelaskan tentang keadaan yang berkaitan dengan berbagai aspek yang dimiliki oleh responden terutama tentang identitas responden. Adapun karakteristik dari responden dengan jumlah 60 orang pada penelitian ini dapat dilihat pada tabel dan gambar berikut:

Tabel 3. Karakteristik responden berdasarkan status

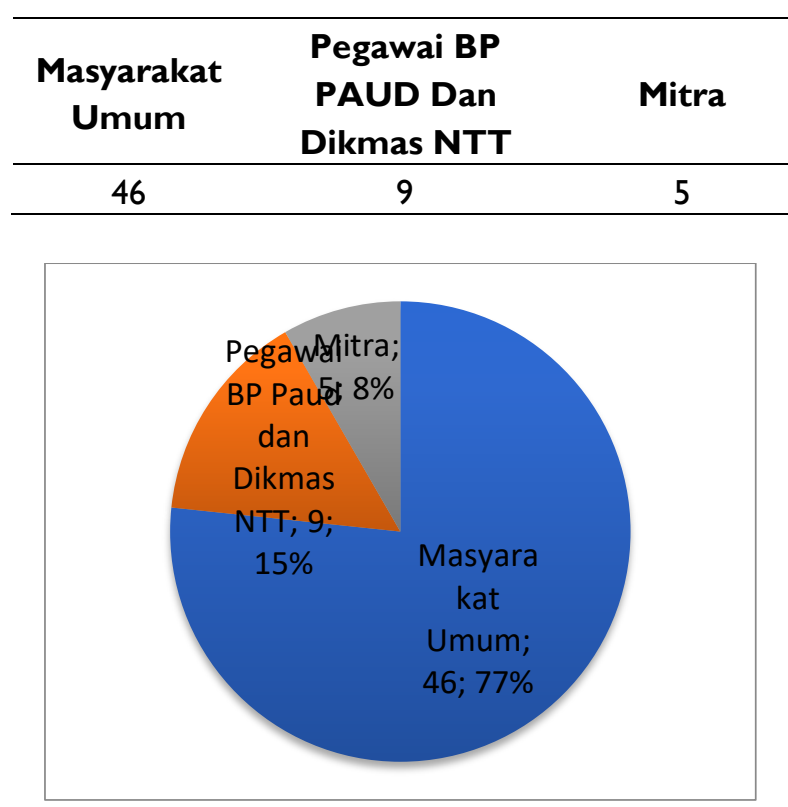

Gambar 3. Grafik karakteristik responden berdasarkan status

Tabel 4. Karakteristik responden berdasarkan jenis

\begin{tabular}{cc}
\multicolumn{2}{c}{ kelamin } \\
\hline Laki-laki & Perempuan \\
\hline 25 & 35 \\
\hline
\end{tabular}

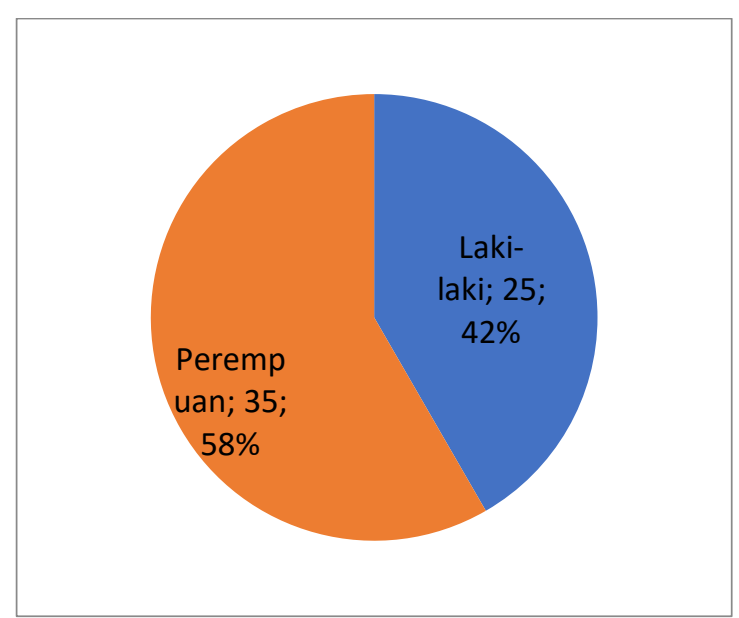

Gambar 4. Grafik karakteristik responden berdasarkan jenis kelamin

Berdasarkan tabel dan grafik karakteristik responden diketahui bahwa mayoritas responden berasal dari kalangan masyarakat umum dengan jumlah 46 orang atau sebesar $77 \%$, kemudian dari kalangan pegawai BP PAUD Dan Dikmas NTT sebanyak 9 orang dengan 


$$
\begin{array}{c|l}
\text { Jurnal Sains Komputer dan Teknologi Informasi } & \text { Page } \\
\text { e-issn: 2655-7460. Volume 3 No.2, Mei 2021 } & \text { 29-39 }
\end{array}
$$

persentase sebesar 15\%, sisanya adalah responden dari kalangan mitra sebanyak 5 orang atau sebesar $8 \%$. Jika dilihat dari jenis kelamin maka mayoritas responden adalah perempuan yang berjumlah 35 orang dengan persentase $58 \%$, dan laki-laki berjumlah 25 orang atau sebesar $42 \%$.

\subsection{Analisis Mean Dan Total Variabel}

Analisis ini dilakukan terhadap hasil jawaban responden terhadap instrumen berdasarkan Teori Literasi Informasi. Instrumen terdiri dari 8 variabel dengan total 22 item pernyataan. Adapun hasil analisis mean dan total variabel terhadap ke-8 variabel pada instrumen penelitian dapat dilihat pada tabel berikut:

Tabel 5. Rekapitulasi hasil analisis mean dan total variabel

\begin{tabular}{ccc}
\hline Nama Variabel & $\begin{array}{c}\text { Total } \\
\text { Variabel }\end{array}$ & Skor \\
\hline Relevansi & 3,88 & 4 \\
\hline Akurasi & 3,47 & 4 \\
\hline Otoritas dan Reputasi & 3,82 & 4 \\
\hline Kekinian & 3,96 & 4 \\
\hline Objektivitas & 3,47 & 4 \\
\hline Cakupan & 3,83 & 4 \\
\hline Bukti yang kuat & 3,58 & 4 \\
\hline Bahasa dan Gaya Penulisan & 3,52 & 4 \\
\hline
\end{tabular}

Terdapat item yang perlu diperhatikan karena hanya memperoleh nilai mean sebesar 3,25 dan 3,38 dan termasuk dalam kategori cukup tinggi yakni item Aku2 dan Aku3. Kedua item tersebut mengukur ada dan tidaknya informasi mengenai pihak yang bertanggungjawab terhadap informasi yang disajikan dan kompetensi penulis atau sumber informasi tersebut. Secara spesifik, pada situs web memang tidak mencamtukan hal-hal tersebut, tetapi sebenarnya pada sub menu Kontak Kami telah memuat informasi tentang lembaga BP PAUD Dan Dikmas NTT.

Item Cakl yang berbunyi "Informasi dalam situs web membahas berbagai hal" memperoleh nilai mean 3,78. Hal tersebut wajar karena setelah diobservasi diketahui bahwa informasi yang disajikan hanya terbatas pada dunia pendidikan saja sesuai dengan tugas dan fungsi dari BP PAUD Dan Dikmas NTT, walaupun informasi tersebut disajikan dalam berbagai format seperti berita, kegiatan dan artikel. Sedangkan item Cak3 dengan bunyi "Terdapat link dalam situs web yang terhubung ke situssitus lain yang dapat dipercaya" juga memperoleh nilai mean terendah yakni 3,72. Jika dibandingkan dengan hasil observasi, hal tersebut bisa diterima karena pada situs web BP PAUD Dan Dikmas NTT hanya memiliki tautan dengan situs web Kemdikbud sebagai afiliasinya.

Item Kek2 yang berbunyi "Informasi yang disajikan dalam situs web selalu diperbarui" memperoleh nilai mean hanya sebesar 3,68, sedangkan item Kekl dengan bunyi pernyataan "Tercantum tanggal kapan halaman situs web tersebut ditulis, dan kapan direvisi atau diedit" memperoleh nilai 4,23. Sehingga nilai total variabel yang diperoleh adalah sebesar 3,96 dengan skor 4 dan termasuk dalam kategori tinggi yang berarti bahwa situs web BP PAUD Dan Dikmas NTT memiliki tingkat kekinian yang tinggi ditunjukkan dengan informasi yang senantiasa diperbarui. Setelah dibandingkan melalui observasi diperoleh perbedaan hasil dengan analisis mean dan total variabel. Untuk kedua item pernyataan pada variabel kekinian, berdasarkan hasil observasi sebenarnya sangat terpenuhi.

Secara keseluruhan, evaluasi yang dilakukan terhadap situs web BP PAUD Dan Dikmas NTT berdasarkan 8 variabel pada Teori Literasi Informasi menunjukkan bahwa situs web tersebut termasuk dalam kategori baik walaupun terdapat banyak indikator yang memperoleh nilai mean yang rendah. Indikator-indikator inilah yang perlu diperhatikan dan menjadi poin penting dalam perbaikan situs web BP PAUD Dan Dikmas NTT ke depan.

\subsection{Perhitungan Poin Usability}

Perhitungan poin usability dilakukan menggunakan metode WEBUSE dengan mengkonversi nilai bobot dari skala Likert yang digunakan sebagai pilihan jawaban dari kuesioner menjadi nilai merit seperti yang telah dipaparkan sebelumnya pada tinjauan pustaka. Adapun hasil konversi dari bobot skala Likert menjadi nilai merit dan hasil perhitungan poin usability dapat dilihat pada Lampiran 6, sedangkan rangkumannya dapat dilihat pada tabel berikut: 
Tabel 6. Hasil perhitungan poin usability

\begin{tabular}{cccccc}
\hline & $\begin{array}{c}\text { Content, } \\
\text { organization and } \\
\text { readability }\end{array}$ & $\begin{array}{c}\text { Navigation } \\
\text { and link }\end{array}$ & $\begin{array}{c}\text { User } \\
\text { interface } \\
\text { design }\end{array}$ & $\begin{array}{c}\text { Performance } \\
\text { and } \\
\text { effectiveness }\end{array}$ & \multirow{2}{*}{ Rerata } \\
\cline { 1 - 4 }$\sum$ Merit & 3,97 & 3,40 & 3,93 & 4,60 & \\
\hline Poin Usability & 0,66 & 0,57 & 0,65 & 0,77 & 0,66 \\
\hline Level Usability & Good & Moderate & Good & Good & Good \\
\hline
\end{tabular}

Secara umum dari ke-4 variabel pada metode WEBUSE yang dievaluasi memperoleh rerata poin usability sebesar 0,66 dan termasuk dalam level "Good". $\mathrm{Hal}$ tersebut dapat dijelaskan bahwa dari segi kegunaan, mayoritas responden mempunyai persepsi bahwa tingkat kegunaan dari situs web BP PAUD Dan Dikmas NTT berada pada kategori yang bagus artinya bahwa situs web tersebut berguna bagi para responden. Dari ke-4 variabel, adalah variabel Navigation and link yang memperoleh poin usability terendah yakni sebesar 0,57 dan hanya termasuk dalam level "Moderate", sedangkan variabel lainnya berada pada level yang lebih tinggi yakni level "Good". Walaupun berada pada kategori "Moderate" dan "Good" akan tetapi setiap indikator pada variabelvariabel tersebut memperoleh nilai merit yang berbedabeda sehingga akan ada item pernyataan yang perlu dibahas secara detail.

\subsection{Kesimpulan Hasil Analisis Dan Rekomendasi Perbaikan}

Analisis terhadap hasil evaluasi dari kedua aspek memperoleh kesimpulan bahwa situs web BP PAUD Dan Dikmas NTT belum sampai pada level top performance walaupun secara keseluruhan sudah baik. Hal itu dikarenakan oleh ditemukannya beberapa permasalahan minor yang tentunya wajib untuk diperbaiki agar meningkatkan kinerja dari situs web tersebut.

Adapun kelebihan-kelebihan yang dimiliki oleh situs web BP PAUD Dan Dikmas NTT yaitu:

a. Informasi yang disajikan relevan dengan kebutuhan pengguna.

b. Domain situs web yang digunakan sangat terpercaya.

c. Informasi yang disajikan kekinian atau selalu diperbarui.

d. Sumber informasi yang disajikan reliabel walaupun belum diinformasikan secara lengkap.

e. Proses pencarian informasi yang berhasil cepat dan tepat. f. Adanya navigasi dan tautan yang mempermudah pengguna.

g. Situs memiliki tampilan yang konsisten serta tidak ada blinking text dan animasi yang mengganggu.

h. Situs web memiliki kecepatan proses yang tinggi.

i. Situs web memiliki hit counter.

Rangkuman rekomendasi perbaikan yang disarankan kepada pihak yang berwewenang berdasarkan hasil analisis adalah sebagai berikut:

a. Lengkapi menu About Us/Tentang Kami/Profil karena situs web harus memuat informasi tentang web ditujukan untuk siapa, digunakan untuk membahas apa, dan dibuat untuk apa.

b. Situs web harus memuat informasi mengenai pihak yang bertanggungjawab terhadap informasi yang disajikan, misalnya sertakan sumber informasi baik informasi eksternal maupun internal seperti siapa yang menulis, siapa yang mengedit dan siapa yang mempublikasikan.

c. Untuk artikel perlu menyajikan informasi lengkap tentang penulis minimal yang menggambarkan kompetensi dari penulis.

d. Situs web tidak hanya mencantumkan tanggal kapan sebuah informasi ditulis, tapi juga mencantunkan tanggal kapan direvisi atau diedit.

e. Menambahkan tautan dengan situs-situs web lainnya yang sekiranya mempunyai afiliasi dengan BP PAUD Dan Dikmas NTT selain situs Kemdikbud serta situs lainnya yang berguna bagi para pengunjung.

f. Hindari penggunaan singkatan yang mungkin tidak familiar bagi pengunjung pada menu ataupun tautan yang disediakan.

g. Pastikan desain antarmuka dan penggunaan warna sesuai dengan prinsip Human Computer Interaction.

h. Halaman yang diminta berdasarkan tautan seharusnya ditampilkan paling atas sehingga pengguna tidak salah kaprah atau kesulitan untuk mencari halaman yang diminta. 


$$
\begin{array}{r|l}
\text { Jurnal Sains Komputer dan Teknologi Informasi } & \text { Page } \\
\text { e-issn: 2655-7460. Volume } 3 \text { No.2, Mei 2021 } & \text { 29-39 }
\end{array}
$$

i. Minimalisir penggunaan scrolling untuk menggulung halaman.

j. Perlu menambahkan layanan lain selain berita, kegiatan dan artikel guna mengakomodir pengunjung dari kalangan masyarakat umum.

k. Perlu memberi perbedaaan antara tautan (link) yang sudah dikunjungi dan yang belum dikunjungi misalnya dengan memberi perbedaan warna.

\section{KESIMPULAN DAN SARAN}

Berdasarkan hasil analisis mean dan total variabel untuk menganalisis kebenaran informasi serta perhitungan poin usability untuk menentukan tingkat kegunaan dari situs web BP PAUD Dan Dikmas NTT dapat disimpulkan bahwa 8 variabel yang digunakan untuk analisis kebenaran informasi berdasarkan Teori Literasi Informasi memperoleh rerata skor 4 atau dikategorikan dalam keadaan baik/tinggi. Hal tersebut mengindikasikan bahwa responden menilai informasi-informasi yang disajikan pada situs web benar atau faktual. Dilihat dari aspek kegunaan, perhitungan poin usability yang dilakukan berdasarkan metode WEBUSE menunjukkan hasil yang positif, yang mana rerata poin usability yang diperoleh adalah sebesar 0,66 atau termasuk dalam level "Good" yang berarti bahwa situs web tersebut berguna bagi para pengunjung. Hasil ini menunjukkan bahwa situs web BP PAUD Dan Dikmas NTT dapat dikatakan telah memenuhi syarat sebagai sebuah media informasi berbasis web yang faktual dan berguna.

Dikarenakan masih terdapat hal-hal yang perlu diperbaiki dan ditingkatkan, oleh karena itu disarankan agar melakukan perbaikan secara substansial sesuai dengan rekomendasi-rekomendasi perbaikan yang telah disampaikan sebelumnya dan perlu untuk dilakukan evaluasi dari aspek lain dengan menggunakan metode yang relevan.

\section{ACKNOWLEDGEMENT}

Penulis mengucapkan terima kasih kepada Kepala BP PAUD Dan Dikmas NTT beserta para pegaawai serta para mitra yang telah memberikan dukungan atas partisipasinya sebagai tempat dan responden penelitian.

\section{DAFTAR PUSTAKA}

Ai Lien, D., Gunawan, A.W., Aruan D.A. dan Kusuma, S. 2014. Literasi Informasi: 7 Langkah Knowledge
Management. Jakarta (ID): Penerbit Universitas Katolik Indonesia Atma Jaya.

Akhsan, A.A. dan Faizah. 2017. Analisis dan Perancangan Interaksi Chatbot Reminder dengan User Centered Design. Jurnal Sistem Informasi (Journal of Information Systems), vol. 13, no. (2), pp. 78-89..

Amri. 2016. Analisis Pemanfaatan Teknologi Informasi Dan Komunikasi Dalam Menunjang Terwujudnya Makassar Sebagai Smart City. Jurnal Komunikasi KAREBA, vol. 5, no. 2, pp. 43I-445.

Azwar, M. 2013. Information Literacy Skills: Strategi Penelusuran Informasi Online. Makassar (ID): Alauddin University Press.

Baltzan, P. dan Philips, A. 2009. Essentials of Business Driven Information Systems. New York (US): McGraw-Hill.

BP PAUD dan Dikmas NTT. 2020. Rencana Kerja Tahunan BP PAUD dan Dikmas NTT Tahun 202I. Ditjen PAUD, Dikdas dan Dikmen Kementerian Pendidikan dan Kebudayaan Republik Indonesia Kupang.

Chiew, K.T. dan Salim, S.S. 2003. WEBUSE: Website Usability Evaluation Tool. Malaysian Journal of Computer Science, vol. 16, no. I, pp. 47-57.

Dahlan, A.I. 2016. Evaluasi Informasi Online pada Situs Web Pusat Perpustakaan UIN Syarif Hidayatullah Jakarta [Skripsi]. Jakarta (ID): Universitas Islam Negeri Syarif Hidayatullah.

Dewi, I.K., Mursityo, Y.T. dan Putri, R.R.M. 2018. Analisis Usability Aplikasi Mobile Pemesanan Layanan Taksi Perdana Menggunakan Metode Webuse dan Heuristic Evaluation. Jurnal Pengembangan Teknologi Informasi dan Ilmu Komputer, vol. 2, no. 8, pp. 29092918.

Hair, J.F., Black, W., Babin, B. dan Anderson, R. 2010. Multivariate Data Analysis. $7^{\text {th }}$ Edition. New York (US): Prentice Hall International, Inc.

Kemdikbud. 2020. Jumlah Data Satuan Pendidikan (Sekolah) Anak Usia Dini per Provinsi : Prov. Nusa Tenggara Timur. Kemdikbud [Internet]. [diakses 14 Oktober 2020]. Tersedia pada: https://referensi.data.kemdikbud.go.id/index21.php ?kode $=240000 \&$ level $=\mathrm{I}$.

Marcus, A. 20I I. Design, User Experience and Usability Part I and Part 2. Orlando (US): Springer. 
Praditya, D. 20I4. Pemanfaatan Teknologi Informasi Dan Komunikasi (TIK) Di Tingkat Pemerintahan Desa. Jurnal Penelitian Komunikasi, vol. 17, no. 2, pp. 129140.

Rochmansjah, H. 2019. Application of Good Governance Principles in Government: Perspective of Public Services. International Journal of Science and Society, vol. I, no. (4), PP. I-8.

Tjiptabudi FMH. 2018. Evaluasi Kegunaan Sistem Informasi Pelintas Batas Wilayah Negara (Sintaswin) Pada PLBN Terpadu di Nusa Tenggara Timur, Jurnal Teknologi Terpadu (JTT), vol. 4, no. I, pp. 44-48. 